\title{
Meningkatkan Kemampuan Bicara Anak Usia Dini Melalui Pembelajaran Menggunakan Media Wayang Modern Karakter Animasi Lucu
}

\author{
Arsan Shanie \\ PIAUD, Fakultas Ilmu Tarbiyah dan Keguruan, UIN Walisongo Semarang \\ arsanshanie@walisongo.ac.id \\ Clarita Nur Fadhilah \\ PIAUD, Fakultas Ilmu Tarbiyah dan Keguruan, UIN Walisongo Semarang \\ clarita@gmail.com
}

\begin{abstract}
One of the developments experienced by early childhood is the ability to speak and speak the language. This can be stimulated by using learning media that can generate children's interest in learning. Modern wayang is a learning medium that can improve children's speaking and language skills. The purpose of this study was to determine the improvement of early childhood speech skills using modern wayang media. This research is qualitative descriptive research. The subjects in this study were children in the Ngaliyan District of Semarang. The results of this study are that children's language skills, creativity and innovation increase after being given learning through modern puppet media. Improved children's abilities include listening, responding to comments, speaking more clearly, sorting ideas, discussing and expanding vocabulary.
\end{abstract}

Keywords : speech skills; early childhood; modern wayang; learning media 


\begin{abstract}
ABSTRAK
Salah satu perkembangan yang dialami anak usia dini adalah kemampuan berbicara dan berbahasa. Hal tersebut dapat dirangsang dengan menggunakan media pembelajaran yang dapat memunculkan minat belajar anak. Wayang modern salah satu media pembelajaran yang dapat meningkatan kemampuan berbicara dan bahasa anak. Tujuan penelitian ini untuk mengetahui peningkatan kemampuan bicara Anak Usia Dini dengan media Wayang modern. Penelitian ini merupakan jenis penelitian dskriptif kualitatif. Subjek pada penelitian ini adalah anak-anak yang berada di lingkungan Kecamatan Ngaliyan Semarang. Hasil pada penelitian ini adalah kemampuan bahasa, kreatifitas dan inovasi anak meningkat setelah diberikan pembelajaran melalui media wayang moder. Kemampuan anak yang meningkat diantaranya menyimak, merespon komentar, berbicara lebih jelas, mengurutkan ide, berdiskusi dan memerluas kosa kata.
\end{abstract}

Kata kunci : kemampuan bicara; anak usia dini; wayang modern; media pembelajaran 


\section{PENDAHULUAN}

Menurut Undang-Undang No 20 Tahun 2003 pada pasal 1 poin ke 4 tentang Sistem Pendidikan Nasional menyatakan bahwa "pendidikan anak usia dini adalah suatu upaya pembinaan yang ditujukan kepada anak sejak lahir sampai dengan usia enam tahun yang dilakukan melalui pemberian rangsangan pendidikan untuk membantu pertumbuhan dan perkembangan jasmani dan rohani agar anak memiliki kesiapan dalam memasuki pendidikan lebih lanjut."(Indonesia and 2003 2006). Masa perkembangan anak usia dini juga sering disebut sebagai usia emas perkembangan (golden age) maksudnya adalah seluruh potensi pertumbuhan dan perkembangan anak dapat berubah dengan maksimal dan masing-masing anak belum tentu memiliki perkembangan yang merata. Tumbuh kembang anak dapat berjalan dengan maksimal bergantung dengan pemberian rangsangan yang tepat dan sesuai yang mana hal ini perlu bantuan dari orang lain seperti orang tua, guru atau orang lain yang berada di lingkungan sekitar anak. Stimulus tersebut dapat merangsang anak dalam Anak dalam meningkatkan pengetahuan dan kemampuan bukan hanya dari dirinya sendiri, tetapi lingkungan yang menentukan serta memberikan konstribusi untuk mendukung proses belajar anak.

Salah satu perkembangan yang terjadi adalah perkembangan bahasa yaitu mampu mengembangkan tata bahasa, menguasai banyak kosa kata, semakin kompleks ucapan - ucapan yang dihasilkan, frase dalam kalimat bertambah, dan bias mengolah kata-kata yang tunggal. Bahasa merupakan media dalam membantu berkomunikasi bagi manusia untuk menyampaikan perasaanya serta pikiran terhadap orang lain. Bahasa dipergunakan sebagai alat untuk menyimpan ide dan gagasan serta semua yang telah dipelajari. Penguasaan bahasa haruslah melalui tahap perkembangan tersendiri sebagai alat komunikasi. Pengembangan bahasa yang dimiliki seorang anak selain berbicara ialah membaca, menulis dan menyimak. Memang bahasa anak pada tahapan usia dini masih belum sempurna, untuk itu potensinya harus dirangsang dengan menggunakan bahasa yang baik dan benar serta komunikasi yang aktif. Berbicara sebagai alat komunikasi mempunyai peran yang sangat penting dalam perkembangan sosial, emosional, dan intelektual. Masa kanak-kanak melakukan komunikasi secara bertahap seperti menangis, tertawa, lalu dengan gerakan seperti menggeleng, mengangguk dan lain sebagainya. 
Perkembangan bahasa dipengaruhi oleh beberapa faktor, yaitu faktor biologis dan lingkungan. Faktor biologis merupakan faktor yang mempengaruhi pengolahan bahasa anak karena bahasa didapatkan sejak lahir ke dunia. Sementara faktor lingkungan, anak dapat belajar dengan melakukan imitasi atau meniru yang dilakukan orang lain yang ada disekitar anak dengan cara mendengar, melihat, dan merasakan. Untuk itu diperlukan rangsangan yang harus diberikan pada anak salah satunya menggunakan media wayang modern (karakter animasi lucu). National Education Association (Arsyad 2011) mengatakan media adalah kumpulan komunikasi dari berbagai bentuk, baik dalam media cetak dan juga berbentuk Audio alat-alat yang digunakan dapat di sederhanakan, mampu terbaca atau dilihat dengan jelas serta didengar dengan baik.

Pertunjukkan wayang sebagai media pengembangan anak usia dini membutuhkan Dalam sebagai pemandu agar anak memahami jalan cerita yang ada pada sebuah cerita pewayangan. Dalang mmiliki peran menyampaikan pesan filosofis atau "piwulang" ajaran mengenai kebaikan dan kebenaran pada kehidupan manusia. Dalang mmiliki peran penting menyiapkan naskah cerita yang bersifat inovatif sesuai kondisi dan kebutuhan cerita, namun tetap memiliki edukasi dan pengenalan budaya tanpa mengabaikan tuntutan masyarakat akan hiburan (Nurhayati, Resti, Suroto, \& Valentinus, 2020). Setelah anakanak memahami jalan cerita mengenai pewayangan maka anak-naka juga harus mempraktekkan pewayangan tersebut dengan cara berperan menjadi seorang dalang. Peran sebagai dalang akan sangat mengembangan kemampuan bahasa dan logika anak usia dini.

Dari pernyataan di atas dapat dikatakan penggunaan media sangat erat kaitanya dengan komunikasi. Penggunaan Teknik Bercerita dengan menggunakan media wayang modern merupakan usaha dalam meningkatkan minat anak terhadap cerita atau dongeng yang disampaikan oleh guru atau orang tua, Membuat anak-anak tidak merasa bosan dan sangat bermanfaat dalam pengembangan otak anak, dapat mengasah pola pikir dan imajinasi anak, kemampuan bahasa dan komunikasi semakin meningkat, menambah kemampuan bersosialisasi dan membangun karakter anak. Untuk itu diharapkan media wayang modern mampu membarikan hasil maksimal dalam upaya meningkatkan kemampuan perkembangan bahasa, dan mengembangkan kemampuan berbicara anak. 


\section{METODOLOGI PENELITIAN}

Penelitian ini memiliki kajian pustaka atau kajian literatur. Kajian pustaka merupakan kegiatan menelaah, mencermati, mendalami, dan mengidentifikasi pengetahuan. Kesenjangan dan kelemahan yang terdapat dalam bidang tertentu tersaji dalam bentuk pustaka yang memiliki perbedaan pandangan dengan penulis tertentu, atau menimbulkan sebuah permasalahan(Setyosari Punaji 2013). Penelitian ini juga merupakan penelitian deskriptif kualitatif yang memiliki fokus penelitian utama yaitu kemampuan bahasa dan berbicara anak.

Landasan kajian pustaka secara umum dapat diperoleh dalam sumber yang dijadikan sebagai pedoman umum. Sumber ini berupa kepustakaan berwujud eksiklopedia, monograp, dan sebagainya. Selain itu, peneliti dapat menggunakan hasil penelitian terdahulu, misalnya jurnal, buku atau sumber acuan lain yang memuat hasil penelitian. Dalam penggunaan sumber pustaka harus bersifat selektif, artinya tidak semua bahan pustaka itu ditelaah untuk menjadi landasan dalam penelitian. Dalam artikel ini, penulis menggunakan sumber primer dan sekunder pada topik masalah meningkatkan kemampuan bicara anak usia dini melalui media wayang modern atau karakter animasi lucu. Penulis berusaha memberikan gambaran bagaimana cara mengembangkan kemampuan bicara anak dengan menggunakan media pembelajaran dengan wayang modern.

\section{HASIL DAN PEMBAHASAN}

Pengertian Kemampuan Bicara Anak Usia Dini dan Media Wayang Modern

1. Pengertian kemampuan bicara anak usia dini

Brown and Yule (Ningsih 2014) mengatakan bahwa Speaking merupakan keterampilan dalam mengolah bahasa atau mrnyampaikan gagasan, perasaan atau gagasan secara lisan. Hal ini sama dengan yang disampaikan oleh Tatigan yaitu berbicara berhubungan dengan kosakata. St. Y. Slamet dan Amir (Yanti, Suhartono, and Kurniawan 2018) berpendapat bicara merupakan aktivitas terampil dalam mengolah pesan lewat bahasa lisan sabagai aktivitas untuk menyampaikan gagasan yang disusun serta dikembangkan sesuai dengan kebutuhan penyimak, hal ini menjelaskan berbicara tidak hanya mengucapkan kata - kata saja, tetapi menekankan penyampaiaan gagasan yang dikembangkan dengan kebutuhan 
penerima informasi. Menurut Hurlock (Rumilasari et al. 2016) berbicara adalah sebuah bentuk bahasa yang menggunakan kata - kata atau artikulasi yang digunakan untuk menyampaikan maksud. Proses pembelajaran bicara pada anak, orang tua memiliki peran yang sangat penting, tanpa bantuan orang tua anak tidak akan mampu barbicara dengan baik

Berdasarkan pendapat beberapa tersebut, berbicara merupakan keterampilan dalam mengolah kata dengan tujuan pesan yang disampaikan dapat dipahami oleh penerima atau penyimak. Untuk dapat berkomunikasi adalah tujuan utama berbicara, komunikasi yaitu menerima dan mengirim pesan antara dua orang sehingga pesan tersebut dapat dipahami. Pemberian stimulasi dapat meningkatkan ketrampilan bicara anak, melatih mengucapkan kata dengan tepat dengan media bercerita yang menarik(Kurniawati n.d.).

Tahapan perkembangan bahasa anak antara lain :

a. Pengucapan kata. Mengucapkan kata dengan cara meniru, kemampuan pengucapan akan bertambah apabila anak barada di lingkungan baru dengan orang - orang yang baru dan kata - kata yang baru.

b. Pengembangan kosa kata. Mengembangkan jumlah kosakata, anak harus dapat mengaitkan arti dengan bunyi, karena terdapat banyak kata yang memiliki arti berbeda.

c. Pembentukan kalimat. Kemampuan menggabungkan kata menjadi kalimat menjadi tata bahasa yang baik dan benar dan dapat dipahami orang lain.

Prinsip perkembangan bahasa anak usia dini diantaranya yaitu :

a. Interaksi

Interaksi yang dilakukan dengan lingkungan sekitar dapat membantu anak memperluas kosakata dan mendapatkan beragam contoh dalam menggunakan kosakata yang tepat.

b. Ekspresi

Merupakan ungkapan perasaan dalam kemampuan bahasa dapat dikembangkan melalui pemberian kesempatan anak untuk mengungkapkan pikiran dan perasaan secara tepat.

2. Pengertian media wayang modern dengan karakter animasi lucu

Media bersumber dari bahasa latin "medius" yang berarti "tengah", perantara atau pengantar. Dalam istilah arab, media berarti pengantar atau perantara pesan dari pengirim untuk si penerima pesan. Media merupakan pengantar pesan yang berasal dari pengirim 
kepada penerima pesan, jadi pengertian media dapat disimpulkan bahwa media adalah semua bentuk penghantar yang digunakan manusia (guru dalam sebuah proses pembelajaran) dalam menyampaikan ide, pendapat atau gagasan yang disampaikan kepada penerima (siswa dalam proses pembelajaran). Media pembelajaran dibagi menjadi dua yaitu media dalam arti luas dan sempit, dalam atri luas media bukan hanya menyangkut media komunikasi elektronik saja tetapi juga mencakup alat - alat sederhana misalnya diagram, bagan, slide yang dibuat oleh guru, sementara dalam arti sempit media pembelajaran meliputi media yang digunakan secara efektif selama proses pengajaran terencana. Pengertian media secara lebih khusus dalam proses belajar mengajar diartikan sebagai alat-alat grafis untuk memproses, menangkap, dan menyusun informasi verbal dan visual. Dalam pendidikan anak usia dini media yang biasa digunakan biasanya dibuat sendiri oleh guru atau imitasi yang dibeli tetapi harus sesuai tema yang terdapat pada rancangan kegiatan mingguan dan kegiatan harian(Riana 2008).

Penggunaan media pembelajaran memiliki beberapa fungsi, diantaranya : (a) Fungsi afektif, Media pembelajaran sebagai fungsi afeksi terlihat dari bagaimana tingkat kenikmatan siswa dalam belajar atau membaca. (b) Fungsi atensi, Media pembelajaran sebagai fungsi atensi yaitu menarik dan mengarahkan siswa agar berkonsentrasi terhadap isi pelajaran yang terkait dengan mekna visual yang di tampilkan. (c) Fungsi komprensatoris, Media pembelajaran sebagai fungsi kompensatoris yaitu memberikan konteks untuk dapat memahami teks membantu siswa lemah dalam membaca dan mengorganisasikan informasi serta mengingatnya kembali. Media pembelajaran barfungsi mengakomodasi siswa yang lambat menerima den memahami pelajaran. (d) Fungsi kognitif, Media pembelajaran sebagai fungsi kognitif dapat terlihat dari penelitian yang mengungkapkan jika gambar memperlancar pencapaiaan tujuan agar dapat memahami dan mengingat informasi atau pesan ang terkandung dalam sebuah gambar.

Kontribusi media pembelajaran menurut (sadiman arif s. 2005) meliputi

a. Penyampaiaan pesan pembelajaran lebih berstandar.

b. Pembelajaran menjadi lebih interaktif dalam menerapkan teori belajar

c. Pembelajaran menjadi lebih menarik. 
d. Kualitas pembelajaran dapat lebih ditingkatkan.

e. Pelaksanaan waktu pembelajaran dapat diperpendek.

f. Pembelajaran dapat dilakukan dimanapun dan kapanpun diperlukan.

g. Peran guru berubah ke arah positif.

h. Sikap siswa yang positif terhadap materi pembelajaran dan proses pembelajaran dapat ditingkatkan.

Alat peraga serta media sangat penting untuk diperhatikan terutama untuk merangsang agar anak aktif dan kreatif. Media pembelajaran sebagai alat untuk membantu keberlangsungan proses pembelajaran antara pendidik dan peserta didik, beragam media pembelajaran dapat digunakan oleh pendidik disesuaikan dengan kebutuhan (Sundari R, Karyono T dan Soeteja Z, S. 2020). Zaman yang semakin modern ini banyak sekali alat peraga yang tersedia dan bisa langsung digunakandi kelas, masalahnya tidak semua bisa memenuhi alat peraga sesuai kebutuhan guru. Bagi sekolah yang mampu menyediakan alat peraga sesuai kebutuhan maka akan memudahkan pekerjaan guru, tetapi bagi sekolah yang belum mampu menyediakan kebutuhan alat peraga maka hal ini akan menjadi pekerjaan rumah bagi guru tersebut.

Wayang merupakan salah satu kebudayaan daerah jawa, menurut Kamus Besar Bahasa Indonesia (KBBI) Wayang memiliki arti boneka tiruan orang yang terbuat dari pahatan kulit atau kayu dan sebagainya, yang dapat dimanfaatkan untuk memerankan tokoh dalam pertunjukan drama tradisional, Budaya dalam bentuk kesenian wayang semakin berkembang pesat dan berkembang seiring zaman yang berfungsi sebagai sarana hiburan dan pendidikan. Sementara arti modern menurut KBBI yaitu sikap dan cara berpikir serta cara bertindak sesuai dengan tuntutan zaman.

Wayang merupakan media pendidikan dikarenakan banyak memberikan ajaran-ajaran baik kepada manusia, baik sebagai individu maupun sebagai anggota masyarakat dan dapat dipakai terutama untuk mengembangkan kemampuan bahasa anak untuk jenjang pendidikan anak usia dini. wayang sebagai media informasi karena dalam segi penampilan sangat komunikatif dan digunakan sebagai alat pendekatan kepada anak untuk memberi informasi dalam menghadapi masalah - masalah kehidupan dan seluk beluknya, wayang sebagai media hiburan karena dipakai sebagai alat pertunjukan di dalam berbagai mcam keperluan sebagai hiburan. 
Wayang sebagai warisan budaya bangsa yang meliputi seni peran, seni suara, seni musik dan lain - lain. Wayang juga bentuk denotative dalam bentuk atau wujud visual yang terus berkembang seiring perkembangan zaman juga digunakan sebagai media pendidikan dan sarana hiburan bagi masyarakat( Shanie, 2020 : 63). Dalam arti secara harfiah wayang berarti bayangan, dan dilihat dari bentuk dan wujudnya adalah sebuah boneka bertangkai dari kulit yang dipahat pipih dan diberi warna atau bisa juga dilukis dengan karakter tokoh-tokoh yang digambarkan. Animasi bukan hal asing bagi anak, animasi adalah salah satu karakter lucu yang menjadi kesukaan anak karena animasi biasanya kita temukan pada film - film tokoh anime atau kartun.animasi merupakan gambar bergerak dari kumpulan berbagai objek yang disusun khusus sehingga bergerak sesuai alurnya yang telah ditentukan pada setiap hitungan waktu. Yang dimaksud objek disini adalah gambar manusia, gambar hewan, gambar gedung, gambar tumbuhan, tulisan teks dan lain sebagainya.

Wayang modern adalah wayang modifikasi berupa gambar tokoh (menggunakan animasi lucu), berasal dari kardus atau karton yang didesain menarik sesuai dengan kesukaan anak - anak, media wayang modern termasuk media visual yang merupakan sebuah gambar tiruan tokoh kartun dan suara yang digunakan adalah suara dari guru yang bercerita, gambar tiruan berupa tokoh - tokoh kartun yang disukai anak serta digunakan sebagai media pembelajaran bagi anak usia dini untuk mengembangkan kemampuan berbicara(Fajrie 2013).

Faktor Kebahasaan Dan Nonkebahasaan

Faktor kebahasaan dan non kebahasaan merupakan Faktor keefektifan berbicara (Pratiwi, Halidjah, and Salimi 2013) dibagi menjadi dua yaitu faktor kebahasaan dan nonkebahasaan

1. Faktor kebahasaan

a. Ketetapan ucapan

Membiasakan diri mengucapkan bunyi- bunyi dengan tepat, pengucapan yang kurang tepat dapat menyebabkan pengalihan perhatian pendengar. Seseorang mamiliki gaya berbahasa tersendiri dan dapat berubah sesuai dengan perasaan, pokok pembicaraan, dan sasaran.

b. Penempatan nada, tekanan, dan durasi yang sesuai

Kesesuaian nada dengan tekanan serta durasi membuat daya tarik dalam berbicara. Terkadang merupakan faktor penentu, walau pembicaraan kurang begitu menarik, Namun karna penempatan nada, 
tekanan,serta durasi akan membuat masalahnya menjadi sangat menarik.

\section{c. Pilihan kata}

Hendaknya kata yang dipilih jelas, tepat dan bervariasi. Maksudnya jelas yaitu mudah dimengerti oleh pendengar. Pendengar akan lebih paham jika kata - kata yang digunakan sudah dikenal, dan kata - kata yang belum dikenal tentu saja akan membangkitkan rasa ingin tahu.

d. Ketepatan sasaran pembicaraan

Menyangkut pemakaian kalimat, gunakan kaalimat yang efektif yang akan meudahkan pendengar menangkap pembicaraannya.

2. Faktor non kebahasaan

a. Sikap yang wajar, tidak kaku, dan tenang

Hal ini akan menjadi kesan pertama untuk menjamin adanya kesinambungan dengan pen-dengar.

b. Pandangan diarahkan kepada lawan bicara Pandangan berbicara sangat membantu dalam kegiatan berbicara, pandangan yang hanya tertuju pada satu arah akan menyebabkan pendengar kurang diperhatikan.

c. Gerak-gerik dan mimik yang tepat dengan Penunjang keefektifan berbicara dapat pula dilakukan dengan gerak - gerik dan mimik yang tepat, karena dapat menghidupkan komunikasi supaya tidak kaku.

d. Penguasaan topik

Penguasaan topik akan menumbuhkan kelancaran dan keberanian, bahkan menjadi faktor utama dalam berbicara(Sari et al. n.d.).

\section{Hubungan Antara Meningkatkan Kemampuan Berbicara Anak Usia Dini dan Penggunaan Media Wayang Modern}

Belajar adalah sebuah proses yang kompleks dan alat peraga sangat membantu dalam peningkatan kemampuan berbicara anak. Berbahasa bukanlah kemampuan bersifat alamiah, kemampuan yang tidak dibawa sejak lahir dan dikuasai dengan sendirinya, tetapi harus dipelajari. Kemampuan bicara anak adalah kemampuan mengucapkan kata - kata untuk menyatakan, mengekspresikan, dan menyampaikan persaan kepada orang lain, perkembangan bicara anak usia dini memerlukan stimulasi yang tepat salah satunya dengan menggunakan media wayang modern. 
Melalui media wayang akan memciptakan suatu pengalaman bagi anak karena dengan media ini dapat mengantarkan perasaan, menimbulkan keasyikan dan membangkitkan semangat dalam belajar meningkatkan kemampuan bicara. Cara terbaik dalam mendorong perkembangan bicara adalah dengan memberikan waktu untuk berbicara kepada anak, dorong anak untuk mengungkapkan pendapat. Dengan menggunakan media ini maka anak akan memilih wayang yang disukai sesuai animasi pilihannya, sehingga anak mudah mengungkapkan keinginannya dan mempratekkan apa yang telah dicontohkan. Biarkan anak bermain dengan teman - temannya agar mudah bersosialisasi dengan sekitarnya, biarkan mereka bermain dan selalu mengawasinya.

Wayang modern adalah salah satu permainan edukatif berupa gambar - gambar animasi untuk meningkatkan beberapa aspek perkembangan khususnya meningkatkan kemampuan berbicara dan kosa kata. Jadi disini guru akan memperlihatkan dan memberikan media wayang modern kepada anak dan memberitahukan apa gambar tersebut kemudian memulai bercerita menggunakan media tersebut, bercerita tentang kisah - kisah lucu dan inspiratif, setelah selesai bercerita kemudian berikan wayang tersebut kepada anak, maka anak akan menirukan dengan bermain wayang tersebut sehingga menambah kosakata dan kemampuan berbicara.

Kelebihan dan Kekurangan dalam Penggunaan Media Wayang Modern terhadap Anak usia dini

1. Kelebihan

Wayang modern sebagai alat menunjang keterampilan berbicara anak, karena mereka melihat atau menyimak langsuang apa yang diceritakan guru melalui wayang tersebut. Kelebihan lain wayang modern ini antara lain,

a. Wayang dapat digunakan sebagai sarana hiburan bagi anak sehingga tidak jenuh dalam proses pembelajaran.

b. Media yang disajikan dalam bentuk tokoh kartun yang menarik sehingga membuat anak lebih tertarik dan mempermudah pemehaman anak dalam proses pembalajaran.

c. Dapat digunakan secara berulang - ulang.

d. Media ini dapat dimainkan secara individu dan kelompok.

e. Wayang ini sebagai alat penunjang materi berbicara. 
f. Wayang merupakan salah satu kesenian lokal yang dikreasikan sesuai usia pemahaman anak yang diperkenalkan kepada generasi muda.

2. Kekurangan

Selain memiliki kelebihan, wayang modern juga memiliki kekurangan atau kelemahan, kelemahan - kelemahan tersebut antra lin adalah :

a. Membutuhkan tempat memadai untuk memperagakannya.

b. Membutuhkan kreativitas dalam membuat dan menggunakan wayang modern.

c. Media ini mudah rusak karena terbuat dari kertas atau kardus.

d. Persiapan untuk penggunaan media ini membutuhkan waktu yang lama.

e. Membutuhkan properti lain selain wayang itu sendiri.

f. Saat bercerita guru memerlukan kreativitas ketika bercerita dengan menggunakan wayang modern.

g. Membutuhkan tempat yang sesuai dengan jalan cerita

Kelebihan dan kelemahan yang dimiliki wayang modern dirasa sesuai jika digunakan sebagai media atau alat penunjang dalam materi pembelajaran anak, melalui media pembelajaran diharapkan keterampilan berbicara anak dapat meningkat secara signifikan(Gusti, Made, and Lestari n.d.).

\section{Cara Pembuatan Wayang Modern (Karakter Animasi Lucu)}

Bahan : kardus atau kertas karton, pensil warna atau bisa menggunakan bahan lain untuk mewarnai, pensil, gunting, potongan bambu kecil, lem atau perekat, tali.

Cara pembuatan :

1) Siapkan bahan - bahan terlebih dahulu

2) Ambil kardus atau kertas karton lalu gambari dengan menggunakan pensil, gambar animasi kesukaan anak misalnya animasi doraemoan, saat menggambar begian tangannya digambar secra terpisah.

3) Setelah selesai menggambar lalu warnai gambar tersebut dengan pensil warna warni, sehingga membuat anak menarik.

4) Lalu gunting gambar sesuai pola dengan rapi.

5) Setelah digunting ambillah sebilah bambu yang telah dipotong untuk gagang wayangnya, rekatkan bambu dan bagian badan wayang dengan lem atau bisa juga dengan tali. 
6) Ambillah bagian tangan animasi lalu ikat dengan badan wauang tadi dengan tali agar bisa digerakkan, jangan lupa kaitkan lagi bagian ujung tangan dengan bambu sebagai pengangan untuk menggerakkan tangan wayangnya.

7) Wayang animasinya sudah siap untuk dimainkan.

Langkah - Langkah Kegiatan Dengan Media Wayang Modern Kegiatan awal :

1) Guru membuka kelas dengan memegang wayang

2) Anak memperhatikan guru saat guru menyiapkan alat peraga wayang.

3) Anak mempersiapkan posisi tempat mereka duduknya dengan rapi

4) Guru mamberikan contoh bagaimana memainkan wayang modern secara sederhana.

5) Setelah itu anak memperhatikan guru saat menunjukkan wayang - wayang yang beraneka macam bentuk dan gambarnya dengan menyebutkan nama - nama tokoh animasi tersebut.

Kegiatan inti :

1) Guru membeitahukan judul cerita yang akan diceritakan kepada anak.

2) Lalu anak mendengarkan guru bercerita sambil melaksanakan dialog atau percakapan antar wayang.

3) Guru menggerakkan wayang secara bergantian sambil bercerita.

4) Setelah selesai bercerita guru membagikan satu persatu wayang - wayang tersebut kepada anak, dan mempersilahkan anak memainkan wayang tersebut dengan teman - temannya.

5) guru mempersilahkan anak-anak untuk bercerita sesuai imaginasinya dengan wayang dan mempersilahkannya maju kedepan kelas

Kegiatan akhir atau penutup.

1) Guru memberikan apresiasi kepada anak yang berani tampil di depan kelas dengan memberikannya hadiah.

2) Lalu guru mengulang kembali dan menyimpulkan kisah yang telah diceritakannya dengan beberapa kosakata sederhana yang mudah difahami anak. 
3) Pengajar menutup pembelajaran menggunakan wayang (Hepy 2017).

Seorang guru juga harus memperhatikan beberapa hal saat bercerita dengan wayang, yaitu :

1) Penggunaan tempat bercerita tidak mesti dilakukan di dalam ruangan, bisa juga di lingkungan atau tempat terbuka yang langsung menyatu dengan alam.

2) Bahasa bercerita menggunakan bahasa yang mudah dipahami anak sehingga anak dapat memahami isi cerita yang diceritakan.

3) Intonasi saat bercerita juga sangat berpengaruh, perubahan naik turunnya harus sesuai dengan peristiwa atau kejadian dalam cerita, supaa cerita yang disampaikan dapat menarik dan tidak terkesan monoton.

4) Peniruan suara terhadap karakter wayang yang berbeda akan membuat anak menjadi semangat dalam nendengarkan cerita wayang.

5) Menghindari mengucapkan kata-kata yang tidak perlu karena dapat memutus rangkaian peristiwa dalam cerita wayang yang disampaikan.

\section{Tujuan dan Manfaat Penggunaan Media Pembelajaran Wayang Modern terhadap Anak usia dini}

Tujuan penggunaan media wayang modern membantu konsentrasi dalam proses pembelajaran, meningkatkan efisiensi dalam proses pembelajaran anak usia dini, menumbuhkan sikap dan ketrampilan dalam bidang perkembangan anak, menciptakan situasi yang mudah diingat anak, memberikan motifasi kepada siswa untuk belajar dengan giat, memberikan pengalaman belajar yang bervariasi dan berbeda kapada anak.

Tujuan utama wayang modern adalah untuk mengembangkan kemampuan bahasa anak, sementara tujuan kemampuan bahasa itu sendiri yaitu :

1) Menyimak, mendengarkan, mempergunakan bahasa lisan dan lebih siap bermain dan belajar.

2) Mendukung anak untuk mendengarkan dengan penuh perhatian.

3) Menggunakan bahasa untuk melukiskan kembali pengalamannya. 
15| Arsan Shanie and Clarita Nur Fadhilah

4) Merespon komentar, perbuatan, pertanyaan yang relevan.

5) Mendengarkan dengan kesenangan dengan merespon cerita, irama, lagu, dan memperbaiki sendiri cerita, musik, dan lagu.

6) Berbicara lebih jelas serta dapat didengar dengan penuh kepercayaan.

7) Menggunakan pembicaraan untuk berpikir jelas, mengorganisasi, mengurutkan ide - ide, kejadian - kejadian dan perasaan.

8) Mempermudah interaksi dengan orang lain, merundingkan rencana kegiatan, serta menunggu giliran dalam percakapan.

9) Mencoba dan menyelidiki dengan suara - suara, kata - kata dan teks.

10) Memperluas kosakata dan meneliti arti suara dari kata - kata baru

Manfaat penggunaan media wayang modern, media ini akan memperlancar interaksi antara guru dengan anak agar pembelajaran lebih komunikatif dan menarik sehingga akan menumbuhkan motivasi belajar anak dan imajinasi anak, makna pembelajaran akan lebih jelas sehingga mudah dipahami oleh anak, wayang modern yang bervariasi akan dapat menguatkan ingatan anak dalam proses pembelajaran, media wayang dapat membantu tugas guru dalam menyampiakan pesan - pesan yang akan diberikan kepada aanak usia dini, mengembangkan motorik halus anak dengan memegang wayang, kemampuan berbahasa juga dapat dikembangkan melalui kegiatan bermain dengan wayang modern(Agnia 2013).

\section{KESIMPULAN DAN SARAN}

Upaya dalam meningkatkan kemampuan Bahasa melalui wayang modern yang digunakan sebagai sarana pembelajaran dapat meningkatkan kemampuan Bahasa pada anak antara lain dapat meningkatkan kemampuan 1)Menyimak, mendengarkan, dan menggunakan bahasa lisan membuat anak lebih siap belajar dan bermain; 2)Mendukung anak untuk mendengarkan dengan penuh perhatian; 3)Menggunakan bahasa untuk melukiskan kembali pengalamannya; 4) Merespon komentar, perbuatan, pertanyaan yang relevan; 5)Mendengarkan dengan kesenangan dengan merespon cerita, irama, lagu, dan memperbaiki sendiri cerita, musik, dan lagu; 6)Berbicara lebih jelas serta dapat didengar dengan penuh kepercayaan; 7)Mempunyai pemikiran yang tepat, mengorganisasi, 
mengurutkan ide-ide, kejadian-kejadian dan perasaan; 8) Mempermudah dalam melakukan hubungan dengan orang di sekitar, berdiskusi, merencanakan aktivitas, serta mampu menyesuaikan diri kapan waktunya untuk berbicara; 9)Mencoba dan menyelidiki dengan suara - suara, kata - kata dan teks; 10)Memperluas kosakata dan meneliti arti suara dari kata - kata baru

Pembelajaran wayang moden dengan karakter animasi lucu merupakan upaya dalam menyelenggarakan pembelajaran anak usia dini secara kreatif dan inovatif, diharapkan wayang modern ini dapat berpengaruh yang sangat signifikan pada kemampuan berbahasa anak usia dini. Melalui media wayang akan memciptakan suatu pengalaman bagi anak karena dengan media ini dapat mengantarkan perasaan, menimbulkan keasyikan dan membangkitkan semangat dalam belajar meningkatkan kemampuan bicara. Disisi lain juga meningkatkan interaksi dalam pembelajaran berjalan dengan baik sehingga anak tidak merasa sungkan dalam bertanya kepada guru saat mengalami kesulitan dalam pemahaman cerita. 


\section{DAFTAR PUSTAKA}

Arsyad, Azhar. 2011. "Media Pembelajaran.” Jakarta Raja Grapindo persada

Fajrie, Nur. 2013. MEDIA PERTUNJUKAN WAYANG UNTUK MENUMBUHKAN KARAKTER ANAK BANGSA Jurnal PGSD-FKIP Universitas Muria Kudus

Gusti, N. I., Ayu Made, and Yeni Lestari. n.d. "PENINGKATAN KEMAMPUAN BACA-TULIS PERMULAAN MELALUI PENGGUNAAN MEDIA WAYANG ABJAD KONTEKSTUAL.” Journal.Unj.Ac.Id.

Indonesia, PR Indonesia-Jakarta: Pemerintah Republik, and undefined 2003. 2006. Undang-Undang Republik Indonesia Nomor 20 Tahun 2003 Tentang Sistem Pendidikan Nasional.

Kurniawati, Yanti. n.d. Meningkatkan Kemampuan Berbicara Anak Melalui Metode Bercerita Dengan Media Big Book Di PPT

Tulip Surabaya 1 MENINGKATKAN KEMAMPUAN BERBICARA ANAK MELALUI METODE BERCERITA DENGAN MEDIA BIG BOOK DI PPT TULIP SURABAYA.

Ningsih, Suwarti. 2014. "Peningkatan Keterampilan Berbicara Melalui Metode Bercerita Siswa Kelas III SD Negeri 1 Beringin Jaya Kecamatan Bumi Raya Kabupaten Morowali." Jurnal Kreatif Online 2(4).

Nurhayati, Resti, B., Suroto, \& Valentinus. (2020). Pagelaran Wayang Kulit sebagai Sarana Pembentukan Karakter Bangsa.

Pratiwi, Eka, Siti Halidjah, and Asmayani Salimi. 2013. "Peningkatan

Kemampuan Berbicara Dengan Menggunakan Media Gambar Berseri Pada Pembelajaran Bahasa Indonesia Kelas I Sd.” Jurnal Pendidikan Dan Pembelajaran Khatulistiwa 2(12).

Riana, Cepi. 2008. Unit 5 MEDIA PEMBELAJARAN.

Rumilasari, Ni Putu Dessy, I. Made Tegeh, Putu Rahayu Ujianti, and S.

Psi. 2016. "Pengaruh Metode Bermain Peran (Role Playing)

Terhadap Kemampuan Berbicara Pada Anak Kelompok A." Jurnal Pendidikan Anak Usia Dini Undiksha 4(2).

Shanie, Arsan. 2020. TENUN SONGKET DESA TANJUNG PINANG KAJIAN SEMIOTIK. Jurnal dimensi seni Rupa dan Desain. Universitas TriSakti. 17 (1) 55-66. 
Sari, Yunita, Thoha B. S Jaya, Lilik Sabdaningtyas, Fkip Universitas Lampung, and Jl Soemantri Brojonegoro No. n.d. PENGARUH AKTIVITAS ALAT PERAGA GAMBAR WAYANG TERHADAP KETERAMPILAN BERBICARA ANAK.

Setyosari Punaji. 2013. Metode Penelitian Pendidikan Dan Pengembangan. jakarta: Prenadamedia group.

Sundari, R., Karyono, T., \& Soeteja, Z. (2020). Pengembangan Buku Pengayaan Bermuatan Lokal Bagi Mahasiswa PGSD. Muallimuna: Jurnal Madrasah Ibtidaiyah, 6(1), 31-43.

Yanti, Nafri, Suhartono Suhartono, and Rio Kurniawan. 2018. "PENGUASAAN MATERI PEMBELAJARAN KETERAMPILAN BERBAHASA INDONESIA MAHASISWA S1 PROGRAM STUDI PENDIDIKAN BAHASA DAN SASTRA INDONESIA FKIP UNIVERSITAS BENGKULU.” Jurnal Ilmiah KORPUS 2(1):72-82. 